\title{
TCOF1 Gene
}

National Cancer Institute

\section{Source}

National Cancer Institute. TCOF1 Gene. NCI Thesaurus. Code C75592.

This gene plays a role in embryonic development. 